\title{
Response to a Case Report titled: De Novo Deletion 17p (del17p) in an Adult T-Cell Prolymphocytic Leukemia as a Rare Presentation
}

Sir,

I read the case report titled De Novo Deletion $17 \mathrm{p}$ (del17p) in an Adult T-Cell Prolymphocytic Leukemia as a Rare Presentation, by Zara-tul-Ain Bashir et al. which published in the latest issue Volume 4, Issue 1, 2019 of your journal.

As stated by the authors, $T$ cell prolymphocytic leukemia is an exceptional condition that characterized with accumulation of lymphocytes not only in blood stream and bone marrow but also in lymph nodes and spleen. In fact, since malignant lymphoyctes originated from post-thymic $\mathrm{T}$ cell, nomenclature as "prolymphocyte" is a misused term.

$\mathrm{T}$ cell prolymphocytic leukemia is a disease of elderly with a median age of 65 years [1]. Elevated leukocyte count (even over 100000/mm3), widespread lymphadenopathy and hepatsplenomegaly are the most common clinical findings in patients with $\mathrm{T}$ cell prolymphocytic leukemia. Anemia and thrombocytopenia may accompany to the course of disease, however, their prevalence is less common than B cell prolymphocytic leukemia [2]. The case presented by the authors in the mentioned report was consistent with the data in literature.

In immunophenotype studies, $\mathrm{T}$ cell prolymphocytic leukemia cells strongly express CD52 CD2, CD3, and CD7 which are pan $T$ cell markers [3]. As mentioned in the article, expression of CD4 and CD8 antigens is variable in these cases. Despite authors reported positive $\mathrm{CD} 3$ in present case, there are no information about CD52 CD2 and CD7 antigens.

Differential diagnosis of $\mathrm{T}$ cell prolymphocytic leukemia includes B cell prolymphocytic leukemia, Adult $\mathrm{T}$ cell leukemia-lymphoma, Mycosis fungoides, Chronic lymphocytic leukemia and Hairy cell leukemia. Discussion of several of these conditions is adequate in the article. However, a detailed differential would be better.

To the best of our knowledge, deletion of $17 \mathrm{p}$ chromosome has not been reported in T-Cell Prolymphocytic Leukemia. Therefore, present case by Zara-tul-Ain Bashir et al. is a unique report.

In conclusion, Adult T-Cell Prolymphocytic Leukemia is a very rare clinical condition that characterized with constitutional symptoms, anemia, thrombocytopenia and marker lymphocytosis. Diagnosis of the disease requires peripheral blood smear, bone marrow biopsy and imunophenotype studies with collaboration of other clinical findings.

\section{REFERENCES}

[1] Melo JV, Catovsky D, Galton DA. The relationship between chronic lymphocytic leukaemia and prolymphocytic leukaemia. I. Clinical and laboratory features of 300 patients and characterization of an intermediate group. Br J Haematol 1986; 63: 377. DOI: $10.1111 /$ j.1365-2141.1986.tb05563.x

[2] Matutes E, Brito-Babapulle V, Swansbury J, et al. Clinical and laboratory features of 78 cases of T-prolymphocytic leukemia. Blood 1991; 78: 3269.

[3] WHO Classification of Tumours of Haematopoietic and Lymphoid Tissues. Swerdlow SH, Campo E, Harris NL, et al. Eds. International Agency for Research on Cancer. Revised 4th ed. Lyon: (IARC) 2017.

Gulali Aktas*

*Address correspondence to this author at Abant Izzet Baysal University Hospital, Department of Internal Medicine, Bolu, Turkey.

Email: draliaktas@yahoo.com

Received: February 23, 2019

Accepted: March 03, 2019

\section{AUTHOR'S REPLY}

Thank you for reading the article, you have asked that why we haven't mention the following markers i.e. CD 52, CD2 and CD 7. We don't have these markers available in our panel and the diagnosis of T-Cell prolymphocytic leukemia was made on CD 3 which is a lineage specific marker and also on the basis of co-expression of CD4 and CD8 which is a feature almost unique to T-PLL $[1,2]$. On the basis of clinical presentation, peripheral blood smear, and immunophenotype studies we made the diagnosis of disease.

\section{REFERENCES}

[1] Matutes E, Brito-Babapulle V, Swansbury J, et al. Clinical and laboratory features of 78 cases of T-prolymphocytic leukemia. Blood 1991; 78(12): 3269-74.

[2] Dearden C. How I treat prolymphocytic leukemia. Blood 2012; 120(3): 538-51.

Zara-tul-Ain Bashir*

* Department of Clinical Hematology, National Institute of Blood Disease \& Bone Marrow Transplantation, Karachi, Pakistan.

E-mail: zara_malik08@hotmail.com 